\title{
EVALUATION OF COMMON CARP Cyprinus carpio L. PERFORMANCE FED AT THREE COMMERCIAL DIETS.
}

\author{
Firas Abdul Malik Al-Jader
}

Ramadan Suleiman Al-Sulevany

School of Animal Production, Department of Animal Production, Faculty of

Agriculture and forestry, University of Dohuk

\begin{abstract}
A growth experiment was accomplished to study common carp nutritional effect on three traditional diets differs from its crude protein contain $(25 \%, 30 \%$ and $35 \%)$. This experiment was carrying out in fish breeding project in the Agriculture and forestry college, Dohuk University in Summel city. Common carp of $150 \pm 5.20 \mathrm{~g}$ body size were stocked in cages each having $1 \mathrm{~m}^{3}$ size and were fed frequently for 90 days. Results show that the highest growth performance were obtained with $30 \%$ protein diet while the poorest one was obtained with $25 \%$ protein diet. FCR ranged from 2.27 to 3.01. While the lowest Protein efficiency ratio were obtained when feeding fish on the diet protein have $35 \%$ cp.
\end{abstract}

\section{INTRODUCTION}

Common carp Cyprinus carpio are among the most successful cultured finfish species in the world because of their fast growth rate. Easy to reproduce as well as have good resistance to disease and handling. Common carp having good tolerance to wide range of environmental conditions and being found in over many countries (Zeitler et al. 1984). Numerous studies have been conducted so as to ascertain the dietary protein requirements of common carp with reported dietary protein requirements ranging from $30 \% \mathrm{CP}$ in the case of pond reared fish and juveniles to over $45 \% \mathrm{CP}$ in the case of fry and fingerlings reared within indoor aquaria (Inayat and Salim, 2005). Protein is the main constituent of the fish body thus sufficient dietary supply is needed for optimum growth. Protein is the most expensive macronutrient in fish diet (Pillay, 1990). So, the amount of protein in the diet should be just enough for fish growth where the excess protein in fish diets may be wasteful and cause diets to be unnecessarily expensive (Ahmad, 2000). Reducing feeding costs could be a key factor for successful development of aquaculture. Protein requirements for optimum growth of the fish seem to be affected by numerous factors such as temperature, salinity, fish age and size, etc. Understanding the protein requirement during the grow-out period is an important thing in fish culture management. Realization of the optimum protein level for cultured fish would help reduce the costs and maximize the feed conversion efficiency (Ahmad et al., 2008). The feed conversion ratio (FCR) is an appropriate way to judge the acceptability and suitability of artificial feed for fish. The information of FCR on locally available ingredients will provide the basis to develop acceptable fish feed. The FCR has also been termed as food quotient or food coefficient. The FCR values of

Received 15/5/2011 accepted 31/10/2011 
various fish feed ingredients for Cirrhinus mrigala under controlled conditions have been estimated by many workers (Seema et al., 2002; Shabir et al., 2003; Jabeen et al., 2004). The aim of research is to determinate the perfect diet for fish depending on its low coast and fast growing for fish. The aim of this research to determined the best commercial fish diet to obtain fastest fish growth with lowest costs.

\section{MATERIALS AND METHODS}

Common carp were collected from fish breeding project at the faculty of Agriculture and forestry -University of Dohuk and re-acclimatized to the experimental conditions and test diets. The experiment was run in nine experimental cages, each having $1 \mathrm{~m}^{3}$ size. Each cage was filled with water up to $75 \mathrm{~cm}$ and the level was maintained throughout the study period. After acclimatization, 30 fish weighing $150 \pm$ $5.0 \mathrm{~g}$ on the average were randomly stocked in each cage. Three replicates were followed for each treatment. Dissolved oxygen and $\mathrm{pH}$ of water was maintained by adding the water daily to the pond which the cages are putting in by using water motor. Each group (three replicates/diet) was fed one of the three types of feeds viz., $\mathrm{D}_{1}$ (low protein), $D_{2}$ (medium protein) and $D_{3}$ (high protein), respectively for 90 days. $D_{1} \& D_{2}$ were obtained from the food and agriculture organization while the last one $\left(\mathrm{D}_{3}\right)$ was bought from Amedy Diet Industry in Summel city in Dohuk Governorate. Growth in terms of body weight was monitored at regular weekly intervals based on the growth of fish; the quantity of feed was adjusted throughout the experimental period. Growth performance and feed efficiency were determined by evaluating a number of growth and nutrient utilization indexes, including specific growth rate (SGR), food conversion ratio (FCR), food conversion efficiency (FCE) and protein efficiency ratio (PER). Means on the same row with different superscripts are significantly different $(\mathrm{P}<0.05)$. Growth performance was determined and feed utilization was calculated as follows:

Table (1): Chemical composition of commercial diets (\% DM).

\begin{tabular}{|l|l|l|l|}
\hline & $\mathrm{D}_{1}$ & $\mathrm{D}_{2}$ & $\mathrm{D}_{3}$ \\
\hline Crude protein & 25 & 30 & 35 \\
\hline Crude lipid & 6.5 & 5.0 & 4.5 \\
\hline Crude ash & 15.8 & 14.5 & 12.6 \\
\hline Crude fiber & 4.5 & 2.6 & 3.8 \\
\hline NFE & 48.2 & 47.9 & 44.1 \\
\hline GE $(\mathrm{Kcal} / 100 \mathrm{~g})$ & 400.46 & 413.47 & 421.13 \\
\hline $\mathrm{ME}(\mathrm{MJ} / \mathrm{Kg})$ & 1352.91 & 1392.52 & 1417.33 \\
\hline
\end{tabular}

Weight gain $=$ Final weight $\left(\mathrm{W}_{2}\right)-$ Initial weight $\left(\mathrm{W}_{1}\right)$. $($ Schmalhusen, 1926).

SGR: Specific Growth Rate = (in final weight-In initial weight)/days. (Brown, 1957).

FCR: Feed Conversion Ratio = Feed intake/ Weight gain. (Uten, 1978).

FCE: Feed Conversion Efficiency = (Weight gain/ Feed intake) X 100.

PER: Protein Efficiency Ratio = Weight gain, g wet fish/ g crude Protein feed. (Osborne et al, 1919). 
NFE $($ nitrogen free extract $)=100-($ protein + lipid + ash + fiber $)($ Ahmad et al., 2008 $)$ $\mathrm{GE}(\mathrm{Kcal} / 100 \mathrm{~g})=$ protein*5.64+fat*9.44+NFE*4.11. (NRC, 1993).

ME: $(\mathrm{MJ} / \mathrm{Kg})=$ protein*18.8+fat*33.5+NFE*13.8. (Smith, 1971)

\section{RESULTS AND DISCUSSION}

Growth performance and feed efficiency for fish fed with feeds $D_{1}, D_{2}$ and $D_{3}$ are shown in table (2). SGR, PER were significantly $(\mathrm{P}<0.05)$ higher in fish fed with feed $D_{2}$ compared to fish fed with feed $D_{1}$ and feed $D_{3}$. But there was no significant $(\mathrm{P}>0.05)$ difference in the FCR and FCE values for fish fed with diets $\mathrm{D}_{1}$ and $\mathrm{D}_{2}$. However, the growth, feed efficiency, PER for fish fed with feed $\mathrm{D}_{3}$ were significantly lower $(\mathrm{P}<0.05)$ than that for feeds $\mathrm{D}_{2}$ and $\mathrm{D}_{1}$.

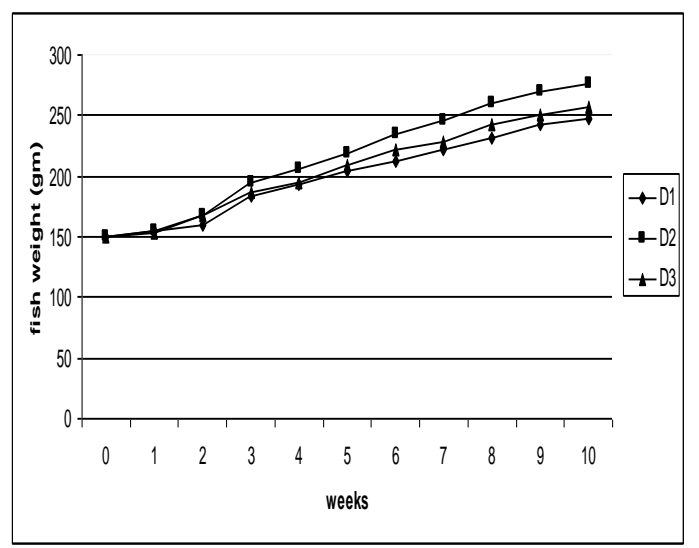

Figure (1): weekly changes in body weight of fish fed three different diets.

Table (2) Growth response of common carp fed at different diets.

\begin{tabular}{|l|l|l|l|}
\hline & $\mathrm{D}_{1}$ & $\mathrm{D}_{2}$ & $\mathrm{D}_{3}$ \\
\hline Initial & $150.11 \pm$ & $150.06 \pm$ & 150.00 \\
weight $(\mathrm{g})$ & 3.27 & 4.47 & \pm 8.11 \\
\hline Final & 199.98 & 216.21 & 205.61 \\
weight $(\mathrm{g})$ & $\pm 6.00 \mathrm{c}$ & $\pm 7.80 \mathrm{a}$ & $\pm 6.57 \mathrm{~b}$ \\
\hline SGR & $0.71 \pm$ & $0.87 \pm$ & $0.76 \pm$ \\
& $0.02 \mathrm{c}$ & $0.05 \mathrm{a}$ & $0.03 \mathrm{~b}$ \\
\hline FCR & $3.01 \pm$ & $2.27 \pm$ & $2.70 \pm$ \\
& $0.12 \mathrm{a}$ & $0.35 \mathrm{~b}$ & $0.64 \mathrm{~b}$ \\
\hline FCE $(\%)$ & $33.22 \pm$ & $44.09 \pm$ & 37.07 \\
& $0.67 \mathrm{~b}$ & $2.31 \mathrm{a}$ & $\pm 1.67 \mathrm{~b}$ \\
\hline PER & $1.02 \pm$ & $1.05 \pm$ & $0.79 \pm$ \\
& $0.16 \mathrm{a}$ & $0.10 \mathrm{a}$ & $0.16 \mathrm{a}$ \\
\hline
\end{tabular}

According to this table the maximum value was recorded for the first group of cages which its value of body weight gain increasing is the top one which the ration consists of $30 \%$ protein while the other two ration value of protein in cage number $1 \& 3$ is $25 \%$ \& 35\% respectively. This results show that although the levels of protein in the $\mathrm{D}_{3}$ is higher than the level in $\mathrm{D}_{2}$ but the maximum value of growth has been recorded in this group. The continues feeding by protein shows a significant increasing in fish weight gain until reaching the ninth week which is similar than the tenth week which 
mean that the continuing feeding is non benefit after the ninth week. Feeding by $\mathrm{D}_{2}$ in the tenth week significant increasing comparing with other diets, while the minimum value is recorded in the first week of feeding. Common carp grew best when fed on the diet $\mathrm{D}_{2}$ containing about $30 \%$ protein. The Common carp fish have been reported in the literature to be omnivorous in feeding habit (Nautiyal 1994), suggesting higher protein and fat requirement during early stages of growth. Feed conversion ratios (FCR) and feed conversion efficiency (FCE) of feed $D_{2}$ was better than that for feeds $D_{1}$ and $D_{3}$. Although there was no statistically significant $(\mathrm{P}<0.05)$ difference between the FCR and FCE of feeds $D_{1}$ and $D_{2}$. Nevertheless FCR and FCE of feed $D_{3}$ were significantly $(\mathrm{P}<0.05)$ poor as compared to that of feeds $\mathrm{D}_{1}$ and $\mathrm{D}_{2}$. The values of FCR and FCE obtained in the current study are comparable to those reported for common carp in earlier studies (Anon 2003).Treer et al. (1998) found that common carp can make good use of dry feeds, yielding entirely acceptable growth performance and feed efficiency.Growth performance of fish with feed $\mathrm{D}_{2}$ surpassed the growth performance of fish fed with feeds $D_{1}$ and $D_{3}$; this may probably be due to the fact that feed $D_{2}$ was manufactured with better high quality ingredients. One has to balance; however, the advantage of using feed $\mathrm{D}_{2}$, as less feed was required to yield a greater amount of fish. From these results it can be concluded that feed $\mathrm{D}_{2}$ was a more profitable feed for common carp. The PER values for fish fed at diet $\mathrm{D}_{2}$ were significantly $(\mathrm{P}<0.05)$ higher compared with fishes fed at $\mathrm{D}_{1}$ and $\mathrm{D}_{3}$, regardless of the fact that feed $\mathrm{D}_{3}$ had higher protein content. This could be attributed to the reason that, the protein sources used to manufacture feed $D_{2}$ may be of high quality than those of feeds $D_{1}$ and $D_{3}$. Moreover, the low fat content of feed $\mathrm{D}_{3}$ may force the fish to use some of the protein as an energy source, thereby reducing protein synthesis and causing growth retardation. Thus, it is conceivable that common carp require more energy (either protein or fat) than can be provided by feed $\mathrm{D}_{3}$. An inadequate dietary $\mathrm{D}_{3}$, resulted in lower growth as well as lower protein as reported in other studies (Webster et al. 1995, Shiau and Lan 1996, Samantaray and Mohanty 1997, Inayat and Salim. 2005, Catacutan and Coloso 1995, Keembiyehetty and Wilson 1998, Zeitler et al. 1984 and Parazo 1990). The growth rate of Common carp fed diet $\mathrm{D}_{3}$ with lower lipid level (4.5\%) was lower compared to fish fed diets $\mathrm{D}_{1}$ and $\mathrm{D}_{2}$ with higher lipid levels (about 6.5\% and 5\%, respectively).The different design of dietary nutrient level affects the estimation of nutrient requirement (Mercer 1982). To achieve better growth, the dietary ingredients should be readily digestible and provide sufficient essential amino acids. However, different ingredients differ in their amino acid composition and availability. It can be concluded that common carp can make good use of dry feeds currently available in the country, yielding entirely acceptable growth performance and feed efficiency. The trend of correlation between FCR and average body weight recorded in the present study matches with the results given by Faturoti (1989), who reported that feed intake, protein intake and FCR were positively correlated with average weight gain. Contradictory results were observed by Shabir et al. (2003). They observed that the correlation between average body weight and FCR values was significant and negative 
in case of wheat bran, whereas in case of sunflower meal and maize gluten the correlation was un significant and negative. Similar results were also observed by Seema et al. (2002), that the correlation between average body weight and FCR values was un significant and negative in case of three ingredients viz. rice polish, maize oil cake and rice broken. In this study, the NFE (48.2, 47.9, 44.1) GE (400.46, 413.47, 421.13) and $\mathrm{ME}(1352.91,1392.52,1417.33)$ for $\mathrm{D}_{1}, \mathrm{D}_{2}$ and $\mathrm{D}_{3}$ respectively. This result is in agreement with Ahmad at al, (2008) who studied the effects of protein level $(25 \%, 35 \%$ and $45 \%)$ for Nile tilapia, and found that the NFE $(56.62,47.11,35.38) \mathrm{GE}$ (439.14, 446.85, 458.92) and ME (1475.14, 1492.37,1527.21) respectively. Results in this study revealed that the reduced growth might be recovered by increasing the dietary protein level for common carp. The optimum dietary protein is $30 \%$ for fish farming in Dohuk where it realized the optimum growth and feed utilization.

\section{ACKNOWLEDGMENT}

The authors are thankful to Dr. Mwafaq S. Barwary, Dean of Faculty of Agriculture and forestry, Dohuk University for his constant encouragement, support and making available requires for the experiments.

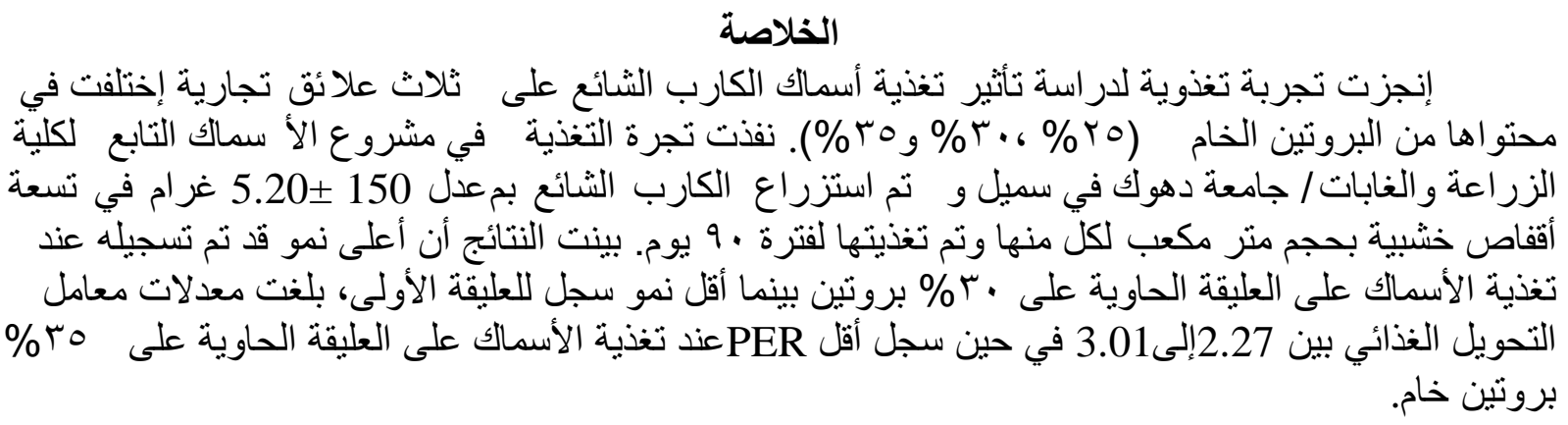

\section{REFRENCES}

Ahmad, M.H. (2000). Improve Productive Performance in Fish. Ph.D. Dissertation, Animal Prod. Department, Faculty of Agriculture, Zagazig University.

Ahmad, M. H., Abdel-Tawwab, M. and Khattab, A. E. Y. (2008). Effect of Protein Level and Stoking Density on Growth Performance, Survival Rate, Feed Utilization and Body Composition of Nile Tilapia Fry (Oreochromis niloticus L.). Fish Nutrition Department and Fish Ecology Department, Central Laboratory for Aquaculture Research, Abbassa, Abo-Hammad, Sharkia, Egypt: 21-34.

Anon, (2003). Annual Report 2002 - 2003, National Research Centre on Coldwater Fisheries. Bhimtal, Uttaranchal, India, 132pp.

Brown, M.E. (1957). Experimentinal studies physiology, Academic Press, New York,p:361-400. 
Catacutan, M.R. and R.M. Coloso. (1995). Effect of dietary protein to energy ratios on growth, survival and body composition of juvenile Asian seabass, Lates calcarifer. Aquaculture 131: 125-133.

Faturoti, E.O., (1989). Effect of supplementary feeding and organic manuring on the production of African Catfish, Clavrias gariepenus. J. West. Afr., Fish, 4: 187195.

Inayat, L. and M. Salim. (2005). Feed conversion ratio of major carp, Cirrhinus mrigala fingerliongs feed on soybean meal, maize and maize gluten of Pakistan Veterinary Journal, 25(1):13-16.

Jabeen, S., M. Salim and P. Akhtar. (2004). Feed conversion ratio of major carp Cirrhinus mrigala fingerlings fed on cotton seed meal, fish meal and barley. Pakistan Vet. J., 24: 42-45.

Keembiyehetty, C.N. and R.P. Wilson. (1998). Effects of water temperature on growth and nutrient utilization of sunshine bass (Morone chrysops X Morone saxatilis) fed diets containing different energy/ protein ratios. Aquaculture 166: 151-162.

Mercer, L.P. (1982). The quantitative nutrient-response relationship. Journal of Nutrition 112: 560-566.

Nautiyal, P. (1994). Mahseer the Game Fish (Natural history, status and conservation practices in India and Nepal). Rachna, Srinagar (Garhwal), Uttaranchal, India. I$6 \mathrm{pp}$.

NRC (National Research Council) (1993). Nutrient requirements of fish. Committee on Animal Nutrition. Board on Agriculture. National Research Council. National Academy Press. Washington DC., USA. p 114.

Osborne, T. B.; Mendel L. B. and Ferry, E. L. (1919). A method for expressing numerically the growth promoting value of protein. J. Biochem. , 37:223-229.

Parazo, M.M. (1990). Effect of dietary protein and energy level on growth, protein utilization and carcass composition of rabbitfish, Siganus guttatus. Aquaculture 86: 41-49.

Pillay T.V.R. (1990). Aquaculture: Principles and practices. Fishing News Book. Blackwell Scientific Publications, Ltd., Oxford, UK. pp. 575.

Samantaray, K. and S.S. Mohanty. (1997). Interactions of dietary levels of protein and energy on fingerling snakehead, Channa striata. Aquaculture 156: 241-249.

Schmlhusen, L. (1926). studien uber washstum and diffrentzieung. III. Die embryonal wachstum skurvedes hiichen. Wilhem Roux arch, entwic klungsmech. Org. p.322-387. (cited by itoar, w. s. ;D. J. Randall and J.R. Brett. Fish physiology. VIII.

Seema, R., M. Salim and M. Rashid, (2002). Performance of major carp Cirrhinus mrigala fingerlings fed on rice polish, maize oil cake and rice broken. Int. J. Agri. Biol., 4: 195-196.

Shabir, S., M. Salim and M. Rashid, (2003). Study on the feed conversion ratio in major carp Cirrhinus mrigala fingerlings fed on sunflower meal, wheat bran and maize gluten 30\%. Pakistan Vet. J., 23: 1- 3. 
Shearer, K.D. (1994). Factors affecting the proximate composition of cultured fishes with emphasis on salmonids. Aquaculture 119: 63-68.

Shiau, S.Y. and C.W. Lan. (1996). Optimum dietary protein level and protein to energy ratio for growth of grouper (Epinephelus malabaricus). Aquaculture 145: 259266.

Smith, R.G. (1971). A method for measuring digestibility and metabolizable energy of feeds. Prog. Fish cult.; 33:p 132-134.

Treer, Tomislav; Safner, Roman; Anicic, Ivica, Kolak, Andrea and Drazic, Maja. (1998). Morphological variation among four strains of common carp Cyprinus carpio in Croatia Department of Fisheries, Beekeeping and Special Zoology, Faculty of Agriculture University of Zagreb, ZagrebDepartment for Data Processing, Croatian Livestock Selection Centre, Zagreb, Croatia:10p.

Uten, F.(1978). Standard methods and terminology in finfish nutrition. Pro. World Smp. Fin fish nutrition and technology, 11,p.20-23, Berlin,1979.

Webster, C.D., L.G. Tiu, J.H. Tidwell, P.V. Wyk and R.D. Howerton. (1995). Effects of dietary protein and lipid levels on growth and body composition of sunshine bass (Morone chrysops X M. saxatilis) reared in cages. Aquaculture 131: 291301.

Zeitler, M.H., M. Kirchgessner and F.J. Schwarz. (1984). Effect of different protein and energy supplies on carcass composition of carp (Cyprinus carpio L.). Aquaculture 36: 37-48. 